\title{
Attitudes among Geography Teachers in Bosnia and Herzegovina toward Geospatial Technology Use: Gender, Age and Regional Differences
}

\author{
Boris Avdić $A^{*}$, Nusret DreškovićA ${ }^{\text {, Ranko Mirić }}{ }^{A}$ \\ Received: November 28, 2019| Revised: February 02, 2020 | Accepted: February 26, 2020 \\ doi: 10.5937/gp24-24223
}

\begin{abstract}
The use of geospatial technology at lower levels of education has become a global tendency. However, Bosnia and Herzegovina is a country that is virtually uncharted in this regard, and the present paper has the main purpose to change that fact. Results of a survey conducted among geography teachers place this country within the entry category. Different attitudes among various groups of teachers (based on gender, age and regional distribution) have also been tested. Although the general hypotheses could not be confirmed, certain specific differences have been found, such as in the use of virtual globes, theoretical knowledge of GIS and willingness to attend educational training courses.
\end{abstract}

Keywords: geospatial technology; GIS; geographical education; geography teachers

\section{Introduction}

In the 21st century, school geography should be understood in its wider context as part of an overall education that must have a contemporary character and be able to respond to the challenges of the present and the future alike. In that regard, certain global trends also relate to geography itself (Kerski, 2015). Technological progress has resulted in a revolutionary change in education. This applies in particular to the computerization and digitalization of teaching and learning processes (Donert, 2014; Karolč́k et al., 2016). It seems to be unambiguous that, in teaching geography, computer technology plays a particularly important role in terms of visualization of geographic contents in a given area (Jo et al., 2016), but also in terms of modelling some general phenomena and processes. The focus on the need to replace those strictly traditional approaches taken to the education process where the student occupies a mere passive position, with a move toward active and critical geogra- phy (Macía Arce et al., 2017), has encouraged the introduction of a Geographic Information System (GIS) and other types of geospatial technologies in the education system (Çepni, 2013; Metoyer \& Bednarz, 2017). Besides GIS, geospatial and geoinformation technologies also require the use of dynamic and interactive maps, virtual globes, remote sensing, GPS, and other devices for augmented reality (Baker et al., 2015; Kerr, 2016; Stojšić et al., 2019).

Despite many advantages and opportunities that GIS provides to the lower levels of education (primary and secondary), the progress made in the field of promoting the use of geospatial technology in classrooms on the global level is pretty slow. Even many highly developed countries, which have the potentials to invest sizable funds in education, have faced obstacles and a number of aggravating factors in this process, which is why the use of modern geotechnological resources in geography and other school subjects

\footnotetext{
A University of Sarajevo, Faculty of Science, Department of Geography, Zmaja od Bosne 33-35, 71000 Sarajevo, Bosnia and Herzegovina; borisavdicpmf@hotmail.com, nusret2109@gmail.com, rmiric@gmail.com

* Corresponding author: Boris Avdić; e-mail:borisavdicpmf@hotmail.com
} 
has not yet reached the desired level (see Höhnle et al., 2016). First steps in the application of this kind of technology in geography teaching were made in 1990s, when the number of studies undertaken on this topic have also seen a more significant level of increase. Anđelković and Pavlović (2015) have classified all scientific studies conducted in this field into three main periods, with critical years of 2000 and 2010 separating them. In the current stage, the interest in the educational dimension of GIS was expanded to cover all continents and a large number of different countries (Kerski et al., 2013). However, over the last two decades, regional disparities in its implementation level have become increasingly evident, and thus this issue has attracted attention of some researchers (Bednarz \& Van Der Schee, 2006; Höhnle et al., 2011; Yuda et al., 2009;).

Kerski et al. (2013) have divided countries into the following three categories, based on the level of their GIS use in secondary education (which could be extended to primary schools too): entry, adoption and invention. In general, the invention category includes highly developed countries, which have a long history of implementation of innovative teaching methods and technologies. Finland is a great example of substantial progress made in this field (Johansson, 2003; Riihelä \& Mäki, 2015). Taiwan, where $84 \%$ of geography teachers have used GIS technology in the classroom (Lay et al., 2013; Wang \& Chen, 2013), also deserves to be mentioned as a country that applied a highly successful strategic model in geographical education. On the other hand, there is a wide variety of countries where GIS is used only by enthusiasts among teachers, while majority of them do not have the skills and know-how required for its application. As a rule of thumb, these countries belong to the so-called entry category. Besides Africa, Latin America and some regions of Asia, most of post-socialist countries in $\mathrm{Eu}$ rope also fall within this category. However, considering the fact that it reached the adoption/development stage, Czech Republic stands out as a significant exception (Král \& Řezníčková, 2013; Svatonová \& Mrázková, 2010), which holds true to some extent for Hungary too (Bartha, 2010; Czigány et al., 2018). Generally, the education systems of post-socialist countries suffer from a number of negative consequences of socioeconomic transition and the slow process of adopting new innovative approaches, which is why the case study of Bosnia and Herzegovina should be considered in this light.

Among all of the post-socialist countries, Bosnia and Herzegovina has suffered the gravest consequences of the transition process, since it was engulfed into the flame of a fierce armed conflict, which took place in the period between 1992 and 1995. The war ended with the Dayton Peace Agreement, which resulted in the creation of a highly complex and dysfunctional administration apparatus in the country, which, in addition to a wide range of already existing socioeconomic problems, has had a negative impact on education as well. In essence, there are three basic types of curricula, which are largely built on ethnic foundations and then additionally modified in each of its administrative subdivisions. The said circumstances have also made the introduction of geotechnologies into the classrooms rather complex. GIS technology first appeared in Bosnia and Herzegovina only after 2000 , when it gradually began to find its place in some government institutions, agencies and private companies. In higher education, GIS was initially introduced in 2005 at the University of Sarajevo (Department of Geography), when the students were enabled to use the ArcGIS software. On the other hand, the introduction of GIS technology into lower levels of education has not been implemented to any significant extent yet (Drešković \& Avdić, 2017). Therefore, this study aims at examining the attitudes of Bosnia and Herzegovina's geography teachers towards geospatial technologies and the possible differences among them, which could be of potential significance for creating any future strategies for geographical education.

\section{Hypotheses}

Together with the global GIS expansion in overall education, the need for research support in this field has also become quite recognizable (Baker et al., 2012). In order to find a solution to this matter, a group of authors created a research agenda for geospatial technologies and learning (Baker et al., 2015). One of the main issues that came into focus of this agenda was the requirement for further professional development of geography teachers in the field of geospatial technologies. At an earlier point at the beginning of this century, a research agenda for cognitive and usability issues in geovisualization was made by another group of authors (Slocum et al., 2001). Individual and group differences have here been defined as one of the major research themes within the scope of the above studies. It was argued that it is fully inappropriate to see the users of geovisualisation as a homogeneous group, since there is an immense number of variables that could have a bearing upon a person's ability to work with this kind of methods, such as their expertise level, culture, sex (gender), age, education, socioeconomic status, etc. By combining and analyzing all these papers in the context of professional development of geography teachers in Bosnia and Herzegovina, it seems to be reasonable to examine any potential differences identified among these teachers in terms of their gender, age and regional distribution. 
Gender-based differences in terms of affinity toward computer technology, as well as in terms of their geographical and spatial skills were more pronounced in the older studies, which show that females were usually being outperformed by males (Busch, 1995; Montello et al., 1999). However, some more recent studies indicate that there is a steady trend of reducing this gender gap (Colley \& Comber, 2003), especially regarding the differences among teachers in how they are able to cope with the educational technology (Sang et al., 2010). Some authors attribute this to the expansion of web-based learning (Clark et al., 2007; Crocco et al., 2008) and the laptop effect (Kay, 2006). Although male teachers still perform better in certain aspects of computer use (Meelissen \& Drent, 2008; Stephens, 2013) or spatial thinking (Shin et al., 2016), the general results in this field of study could be understood as mixed, due to a number of studies where such differences were not found (Lay et al., 2013; Teo, 2008). The use of GIS was also discussed from the point of view of feminist geography (Kwan, 2002; Sharp, 2005).

Along with the gender factor, many studies have also tried to explore the age differences in terms of computer technology use (Afshari et al., 2009; Mead et al., 1999; Schubert et al., 2012). Results usually show that younger teachers tend to be more comfortable with the use of computers and geospatial technologies, such as GIS in particular (Kim et al., 2011), but this does not necessary mean that they are using them more often in the classroom compared with their older and/or more experienced colleagues (Russel et al., 2003). In the present study, the age of 43 is taken as the critical age drawn as a clear cut-off line between the younger and older groups of respondents, which is based on the sample's mean and median values.

Regional differences between geography teachers could be anticipated to arise as a result of urban-rural differentiation between certain spatial units. Compared with the predominantly rural areas, the regions with higher levels of urbanization usually have the more favorable socioeconomic conditions that are conducive to a higher degree of overall progress, including a higher level of technological modernization of the educational process itself (Howley et al., 2011). However, information technologies can be seen as an efficient tool used to overcome some education issues in remote rural areas (Arnold et al., 2005). As far as the case study of Bosnia and Herzegovina is concerned, it seems like an obvious choice to take Sarajevo Canton and Central Bosnia Canton as statistically most representative regions. These two cantons have been selected on account of regional disparities between them, as well as on account of the fact that they are sufficiently large to enable the taking of an adequate sample of geography teachers. Sarajevo Canton is the most densely populated and most economically developed part of Bosnia and Herzegovina, with an urbanization rate of $86 \%$ according to the latest 2013 Population Census statistics. On the other hand, Central Bosnia Canton is one of the most prominent rural regions in the country with an urbanization rate of only $30 \%$ and none of its towns has more than 20,000 inhabitants.

Having in mind the above circumstances prevailing in Bosnia and Herzegovina and worldwide, but also the current trends in research concerning the educational use of geospatial technologies, it seems appropriate to put forward the following three main hypotheses in this study:

1. There are significant gender-based differences among geography teachers in terms of the respondents' affinity towards geospatial technology in a representative sample;

2. There are significant age-based differences among geography teachers in terms of the respondents' affinity towards geospatial technology in a representative sample;

3. There are significant regional distribution differences (urban vs. rural) among geography teachers in terms of the respondents' affinity towards geospatial technology in a representative sample.

\section{Methodology}

In order to explore the perceptions and attitudes among the geography teachers about the use of geospatial technology in the education process, this study was designed in the form of survey, as the most effective and conspicuous method. In this case, the survey was conducted on a voluntary basis immediately after the lectures were delivered about the use of GIS and geospatial technologies, which were otherwise an integral part of the regular teachers' professional development training courses held during 2018 in each canton separately. The survey included a total of 83 respondents, but since one of them failed to answer the majority of the questions, the total number of respondents taken into account in the sample was reduced by one $(n=82)$. The sample included geography teachers from Sarajevo Canton (51 teachers) and from Central Bosnia Canton (31 teachers). It covered more than one half of the geography teachers in both regions. Most of the surveyed teachers work only in elementary education $(78 \%)$, of whom approximately 
$55 \%$ teach geography only, while the rest of them also teach some other school subjects in addition to geography (mostly history).

Table 1. Sample structure

\begin{tabular}{|l|c|}
\hline Male teachers & 28 \\
\hline Female teachers & 54 \\
\hline Younger teachers (under 43 years) & 38 \\
\hline Older teachers (43+ years) & 38 \\
\hline Teachers of unknown age & 6 \\
\hline $\begin{array}{l}\text { Teachers from Sarajevo Canton (predominantly urban } \\
\text { region) }\end{array}$ & 51 \\
\hline $\begin{array}{l}\text { Teachers from Central Bosnia (predominantly rural } \\
\text { region) }\end{array}$ & 31 \\
\hline Total sample size & 82 \\
\hline
\end{tabular}

The survey was conducted by using a set of printed questionnaires, which were disseminated to all participants of professional training. Although it was anonymous, the survey required from the respondents to provide their basic demographic information, such as gender, age and work experience. Information about the region (canton) where they are employed as teachers was coded instantly by the researchers. The main part of survey was focused directly on the teachers' affinities and practices regarding the educational use of geospatial technologies, such as GIS in particular. It consisted of 23 close-ended questions, 16 of which included items from a linear 5-point Likert scale, and it was used for the purpose of testing the previously made hypotheses.

The results obtained in the survey were processed by using the required descriptive and inferential statistics. The descriptive results are reflected primarily in the percentage share of the selected options. With regard to the questions that included the Likert items, the arithmetic mean $(\bar{x})$ was also calculated. The Likert items were quantified within the usual range of eval- uation scores, where the most favorable answer in the context of the modernization of geographical education scored 5 points, and the least favorable 1 point. An equal point interval was established within the range of the five responses on the scale. The descriptive analysis in this study provides a general overview of the current status concerning the modernization of geography teaching in Bosnia and Herzegovina, including the predispositions for implementation of GIS-based concept at the primary and secondary level of education.

Inferential statistics methods are used to test the hypotheses and make an analysis of differences in the responses among different groups of respondents. For that purpose, two-tailed Student's t-test has been used as the tool for computing the statistical significance of the difference between the parameters inferred from the data set. Although there are major differences in the views about the reasonable choice of an adequate statistical method for inferential analysis of the data collected through the Likert scale, the ttest proves to be a fairly common and reliable statistical test used for this particular purpose (De Winter \& Dodou, 2010). In this research study, the test was conducted with regard to the mean values calculated by taking into account the answers received from a range of different respondent groups that were interpreted on the basis of the their gender, age and region. Thus, the differences were tested on the basis of the existing independent variables in accordance with each individual question, which in this sense could be regarded as a measure for making a separate sub-hypotheses. However, for the purpose of examining the previously established general hypotheses, the next step was to calculate the mean of the mean values for each individual respondent's answer within the same group variable. The values calculated in this way were then tested with the Student's t-test, where the p-value indicates the statistical significance of their differences by the standard margin $(\alpha=.05)$.

\section{Results}

Out of the total number of the surveyed teachers, about $78 \%$ of them were able to say with certainty that they have heard about GIS before. Those who at least have some basic knowledge of the subject have indicated that they learned about it mostly in the first decade of this century, particularly after 2005, which coincides with the introduction of GIS technology in higher education at the University of Sarajevo. The highest number of the respondents have pointed out that they gained the initial knowledge of GIS through their professional education $(30 \%)$ or their university studies (29\%). However, only $17 \%$ of the teachers have had the opportunity to learn a bit more about GIS during their studies. Approximately the same percentage of the respondents have had a direct contact with GIS technology so far, while $11 \%$ of the surveyed respondents have had one of the GIS software packages installed on their own computers. According to the answers collected from them, some kind of GIS software is currently available in only $6 \%$ of schools.

In addition to the basic information, the following Likert items-based questions have provided a clearer picture of the practices and affinities of the teachers regarding GIS technology and other forms of geotech- 
nological innovation in the teaching process. Over $80 \%$ of the respondents have circled the lowest level option for their own theoretical knowledge of GIS, the skills of using it, as well as the skills to use it in the classroom. However, it is encouraging to note that $78 \%$ of them have mentioned GIS to their students at least once during their lectures so far. On the other hand, only $18 \%$ of the surveyed teachers $(n=55)$ are recorded to have used GIS for teaching preparation at least once, $21 \%(\mathrm{n}=57)$ as a means of demonstration in the classroom, and only $14 \%(n=57)$ have enabled their students to use GIS. It is worth noting that in these questions the sample size was reduced, since a significant number of responses had to be removed from the aggregate results due to an inconsistency with some previous responses, which is probably due to the lack of understanding of the main point of these questions on the part of the respondents.

The answers were more favorable to some extent when it comes to other types of modernization in geographical education. This applies to the fieldwork, the use of virtual globes such as Google Earth, other geovisualization softwares, and GPS. Opinions regarding the future development could be reported as fairly positive. The vast majority of the respondents $(86 \%)$ have expressed an interest in attending educational workshops on the utilisation of GIS in geography teaching, and almost half of them have expressed a particular desire for it. Also, 73\% of teachers are planning to use GIS in the educational process in the future. Over $80 \%$ of them agree that GIS should be introduced into geography education on the secondary school level, while somewhat lower value of the responses has been found in the context of primary education and extracurricular activities.

This Likert items-based group of questions is also considered within the framework of inferential statistics. Regarding the first hypothesis, the t-test analysis was focused on gender differences. To as many as 12 out of 16 questions from this group, the male teachers gave more favorable answers, but a statistically significant difference was found only in three cases. It was thus established that the male teachers evaluate their level of theoretical knowledge of GIS as significantly higher compared with their female colleagues $(\mathrm{t}=2.147, \mathrm{p}=.037)$. They also mention GIS more often in the classroom $(t=2.750, p=.008)$ and use virtual globes $(t=3.268, p=.002)$ in lessons more frequently. On the other hand, the female teachers are more likely to believe that the use of GIS technology should be part of geographical education, which refers in particular to geography in secondary schools $(t=-2.199, p=.034)$. Taken overall, in line with the generally required level of statistical significance $(\alpha=$

Table 2. Results of five-point Likert items based questionnaire on teachers' practices and attitudes towards geospatial technology

\begin{tabular}{|c|c|c|c|c|c|c|c|c|}
\hline Questions & $\mathrm{n}$ & $1(\%)$ & $2(\%)$ & $3(\%)$ & $4(\%)$ & $5(\%)$ & $\bar{x}$ & SD \\
\hline Theoretical knowledge about GIS & 81 & 56.8 & 17.3 & 24.7 & 1.2 & 0.0 & 1.70 & 0.89 \\
\hline Skills of using GIS technology & 81 & 58.0 & 17.3 & 23.5 & 1.2 & 0.0 & 1.68 & 0.88 \\
\hline Skills of using GIS technology in the teaching process & 81 & 58.0 & 19.8 & 21.0 & 1.2 & 0.0 & 1.65 & 0.85 \\
\hline Frequency of mentioning the GIS in the teaching process & 79 & 21.5 & 39.2 & 34.2 & 5.1 & 0.0 & 2.23 & 0.85 \\
\hline Frequency of using GIS for preparation of the teaching process & 55 & 81.8 & 5.5 & 7.3 & 5.5 & 0.0 & 1.36 & 0.85 \\
\hline $\begin{array}{l}\text { Frequency of using GIS as a demonstration aid in the teaching } \\
\text { process }\end{array}$ & 57 & 78.9 & 10.5 & 5.3 & 3.5 & 1.8 & 1.39 & 0.88 \\
\hline Frequency of giving opportunity to students to use GIS & 57 & 86.0 & 5.3 & 8.8 & 0.0 & 0.0 & 1.23 & 0.60 \\
\hline Frequency of using virtual globes in the teaching process & 78 & 32.1 & 19.2 & 34.6 & 9.0 & 5.1 & 2.36 & 1.17 \\
\hline $\begin{array}{l}\text { Frequency of using other geovisualization softwares in the } \\
\text { teaching process }\end{array}$ & 79 & 25.3 & 30.4 & 38.0 & 2.5 & 3.8 & 2.29 & 1.00 \\
\hline Frequency of conducting the fieldwork with students & 79 & 11.4 & 29.1 & 39.2 & 16.5 & 3.8 & 2.72 & 1.00 \\
\hline $\begin{array}{l}\text { Frequency of using geolocation technology in the teaching } \\
\text { process }\end{array}$ & 79 & 38.0 & 30.4 & 24.1 & 6.3 & 1.3 & 2.03 & 1.00 \\
\hline Attitude towards future use of GIS in the teaching process & 80 & 2.5 & 2.5 & 22.5 & 45.0 & 27.5 & 3.93 & 0.91 \\
\hline Interest for attending GIS educational training & 81 & 1.2 & 3.7 & 8.6 & 38.3 & 48.1 & 4.28 & 0.87 \\
\hline $\begin{array}{l}\text { General attitude towards introduction of GIS in the primary } \\
\text { schools }\end{array}$ & 81 & 1.2 & 4.9 & 19.8 & 42.0 & 32.1 & 3.99 & 0.92 \\
\hline $\begin{array}{l}\text { General attitude towards introduction of GIS in the secondary } \\
\text { schools }\end{array}$ & 78 & 1.3 & 2.6 & 14.1 & 37.2 & 44.9 & 4.22 & 0.88 \\
\hline $\begin{array}{l}\text { General attitude towards introduction of GIS in the } \\
\text { extracurricular activities }\end{array}$ & 80 & 0.0 & 2.5 & 25.0 & 51.3 & 21.3 & 3.91 & 0.75 \\
\hline
\end{tabular}


Table 3. Mean values $(\bar{x})$ for different groups of geography teachers

\begin{tabular}{|c|c|c|c|c|c|c|}
\hline \multirow{2}{*}{ Questions } & \multicolumn{2}{|c|}{ Gender differences } & \multicolumn{2}{|c|}{ Age differences } & \multicolumn{2}{|c|}{ Regional differences } \\
\hline & Male & Female & Younger & Older & Urban & Rural \\
\hline Theoretical knowledge about GIS & $2.00 *$ & 1.55 & 1.74 & 1.57 & 1.82 & 1.52 \\
\hline Skills of using GIS technology & 1.89 & 1.57 & 1.71 & 1.59 & 1.76 & 1.55 \\
\hline Skills of using GIS technology in the teaching process & 1.82 & 1.57 & 1.79 & 1.46 & 1.68 & 1.61 \\
\hline Frequency of mentioning GIS in the teaching process & $2.57^{*}$ & 2.04 & 2.32 & 2.11 & $2.43^{*}$ & 1.90 \\
\hline $\begin{array}{l}\text { Frequency of using GIS for preparation of the teaching } \\
\text { process }\end{array}$ & 1.42 & 1.33 & 1.38 & 1.38 & 1.34 & 1.40 \\
\hline $\begin{array}{l}\text { Frequency of using GIS as a demonstration aid in the } \\
\text { teaching process }\end{array}$ & 1.40 & 1.38 & 1.48 & 1.33 & 1.34 & 1.47 \\
\hline $\begin{array}{l}\text { Frequency of providing students with the opportunity to } \\
\text { use GIS }\end{array}$ & 1.30 & 1.19 & 1.21 & 1.28 & 1.22 & 1.25 \\
\hline Frequency of using virtual globes in the teaching process & $2.93 *$ & 2.04 & 2.50 & 2.18 & $2.59 *$ & 1.97 \\
\hline $\begin{array}{l}\text { Frequency of using other geovisualization softwares in } \\
\text { the teaching process }\end{array}$ & 2.61 & 2.12 & 2.34 & 2.20 & 2.24 & 2.37 \\
\hline Frequency of conducting the fieldwork with students & 2.96 & 2.59 & 2.84 & 2.57 & 2.80 & 2.60 \\
\hline $\begin{array}{l}\text { Frequency of using geolocation technology in the } \\
\text { teaching process }\end{array}$ & 2.29 & 1.88 & 2.13 & 1.86 & 1.94 & 2.17 \\
\hline $\begin{array}{l}\text { Attitude towards future use of GIS in the teaching } \\
\text { process }\end{array}$ & 3.93 & 3.92 & 4.03 & 3.86 & 3.94 & 3.90 \\
\hline Interest for attending a GIS educational training & 4.21 & 4.32 & $4.55^{*}$ & 4.08 & 4.25 & 4.33 \\
\hline $\begin{array}{l}\text { General attitude towards introduction of GIS in the } \\
\text { primary schools }\end{array}$ & 3.79 & 4.09 & 4.03 & 3.97 & 3.88 & 4.17 \\
\hline $\begin{array}{l}\text { General attitude towards introduction of GIS in the } \\
\text { secondary schools }\end{array}$ & 3.88 & $4.38^{*}$ & 4.16 & 4.29 & 4.16 & 4.32 \\
\hline $\begin{array}{l}\text { General attitude towards introduction of GIS in the } \\
\text { extracurricular activities }\end{array}$ & 3.93 & 3.90 & 3.89 & 3.94 & 3.90 & 3.93 \\
\hline
\end{tabular}

* Values that are significantly higher than those from the comparative group $(\alpha=.05)$

.05), the first hypothesis about the existence of significant difference between the male and female geography teachers could not be accepted $(t=1.332, p=.191)$, despite the confirmed disparities that have occurred with regard to several indicators specified in some of the above parameters.

Compared with the case of gender, the age-based differences among the teachers concerning the use of GIS and other geospatial technologies have been proven to be even less significant. Somewhat more affirmative answers to the majority of the questions have been provided by the teachers in the younger age group (under 43 years), but a significant difference has been identified in only one case. Specifically, the existence of a considerably higher level of interest in attending GIS education workshops $(t=2.611, p=.011)$ has been recorded among the teachers in the younger age groups. On the other hand, the answers to certain other questions have revealed some surprising results. Thus, for example, to some extent the older teachers tend to believe more often that GIS technology should become an integral part of secondary education and extracurricular activities. Ultimately, the second hy- pothesis that the younger teachers have more positive attitudes towards the introduction of geospatial technologies into the classroom could not be confirmed ( $t$ $=1.023, \mathrm{p}=.308$ ).

The third hypothesis was tested by using the same questions as those formulated in the previous cases, but this time in the context of a comparison made between Sarajevo as a predominantly urban region and Central Bosnia as a predominantly rural region. Contrary to expectations, to some extent the teachers from the Central Bosnia region have responded more favorably compared to their colleagues from Sarajevo Canton. However, a statistically significant difference has been recorded in the responses to two specific questions, where the recorded values were higher for the group of teachers coming from the urban region. It was found that the geography teachers from Sarajevo tend to mention GIS more often during their classes $(t=2.881, p=.005)$ and they use virtual globes in teaching more frequently $(t=2.546, p=.013)$. However, due to the very mixed answers to the remaining questions, there has been no confirmation of the general hypothesis that the geography teachers from Sa- 
Table 4. Inferential statistics (t-test) for general (null) hypotheses

\begin{tabular}{|c|c|c|c|c|c|c|}
\hline \multicolumn{2}{|c|}{ Hypotheses } & \multicolumn{2}{|c|}{$\bar{x}$} & $\mathrm{t}$ & $d$ & $p$ \\
\hline \multirow{2}{*}{$\mathrm{H} 1$} & \multirow{2}{*}{$\begin{array}{l}\text { General gender } \\
\text { differences }\end{array}$} & Male & Female & \multirow{2}{*}{1.322} & \multirow{2}{*}{0.32} & \multirow{2}{*}{.191} \\
\hline & & 2.76 & 2.57 & & & \\
\hline \multirow{2}{*}{$\mathrm{H} 2$} & \multirow{2}{*}{$\begin{array}{l}\text { General age } \\
\text { differences }\end{array}$} & Younger & Older & \multirow{2}{*}{1.023} & \multirow{2}{*}{0.25} & \multirow{2}{*}{.308} \\
\hline & & 2.70 & 2.56 & & & \\
\hline \multirow{2}{*}{$\mathrm{H} 3$} & \multirow{2}{*}{$\begin{array}{l}\text { General regional } \\
\text { differences }\end{array}$} & Urban & Rural & \multirow{2}{*}{0.821} & \multirow{2}{*}{0.20} & \multirow{2}{*}{.418} \\
\hline & & 2.67 & 2.57 & & & \\
\hline
\end{tabular}

rajevo Canton, as an urban region, have a greater affinity for the use of geospatial technologies compared with their colleagues who come from Central Bosnia $(\mathrm{t}=0.821, \mathrm{p}=.418)$.

\section{Discussion and conclusions}

Since this is the very first study of its kind conducted in Bosnia and Herzegovina, it is also one of the pioneer studies in the field of geospatial technologies use in education in the Southeast Europe. Its main purpose was to assess the situation in the country's primary and secondary schools regarding the place that geospatial technology occupies in geography education, with a special focus on the conditions for the implementation of the GIS concept. Its results indicate that there are generally unfavorable conditions for GIS integration into the teaching process, since a vast majority of geography teachers have never used such software at all. Even among those who have had an opportunity of using it, there are only a few enthusiasts who have actually introduced it into the classroom. These findings are comparable with those reported in some of the neighboring and adjacent countries, such as Serbia (Komlenović et al., 2013), Turkey (Demirci, 2009), Greece and Hungary (Bartha, 2010), as well as in some of economically less developed countries in other regions, such as Rwanda in Africa (Akinyemi, 2016). This survey has confirmed the assumption that Bosnia and Herzegovina belongs to the entry category according to the classification suggested by Kerski et al. (2013). There are parallels also with some early findings from the countries that are now considered to be part of the invention category, such as the USA and Finland (Johansson, 2003; Kerski, 2003). For countries like Bosnia and Herzegovina, the experience these countries have gained in the process can be used as a path to follow. In this regard, it is worth noting that a vast majority (86\%) of the surveyed teachers have expressed willingness to attend eventual forthcoming educational training workshops or sessions organized on the topic of GIS use in education. Also, the fact that other forms of geospatial technology (such as virtual globes or other forms of educational software) have already been used by many teachers in geography classes, can be regarded as a significant step forward towards an efficient modernization of the teaching process.

The concept of learning and teaching through GIS appears to be a novelty for teachers in Bosnia and Herzegovina, for both those coming from the younger and those from the older age groups. The same applies to regional differences. This fact undoubtedly explains why neither of the three general hypotheses in this study could be confirmed. Due to the absence of any significant difference in the general average score between the male and female respondents, the conclusion that gender does not play any further direct role in terms of the teacher's attitudes towards information technology (Sang et al., 2010) can be supported by this study. On the other hand, in a more specific context, it is found that the male teachers have demonstrated a significantly higher theoretical level of knowledge about GIS (or at least they claim so) and that they mention GIS more often in their classes. The male teachers have also claimed that they use virtual globes, such as Google Earth, more frequently than the female teachers in the sample. This finding is consistent with Stephens's (2013) study on GeoWeb applications. Another finding is that virtual globes are used significantly more often in the classes by the teachers from urban regions too. These findings about virtual globes, along with a relatively high value of standard deviation, have made this particular question a very reliable parameter for measuring the discrepancies in terms of modernization of geographical education in Bosnia and Herzegovina. Unsurprisingly, the only age-related difference that has been found to be significant in the respondents' attitudes is their willingness to attend professional training designed for the purpose of GIS use. Similarly, Kim et al. (2011) have also reported that younger teachers in South Korea are more likely to participate in this kind of activities.

There are numerous recommendations in other studies about how to make progress in the imple- 
mentation of GIS approach in geographical education on the primary and secondary level. Many authors have emphasized the importance of teacher training, which is one of the external conditions that need to be met in order to encourage and support any further development of this educational concept (Bednarz \& Van Der Schee, 2006). Pre-service teacher geography and GIS intervention (Collins \& Mitchell, 2019), as well as sustained quality professional development for in-service teachers (McClurg \& Buss, 2007) are suggestions that can serve as the guiding principles in the achievement of the main goals in this and many other education fields. However, in the countries that are facing multiple organizational and financial problems, such as Bosnia and Herzegovina, the efforts to turn those kinds of plans into reality could be undermined by a number of challenges encountered in the process. Therefore, an optimal strategy should be to take a step-by-step approach. Extremely ambitious instant and ready-made projects, such as the immediate introduction of complex GIS softwares into education practice would probably result in resistance and rejection by the majority of teachers and thus ultimately fail. The present study shows that there are teachers who already use some type of geospatial technologies actively in their teaching process. Their experience should be used to encourage other teachers to follow suit perhaps even through peer-coaching. As far as GIS is concerned, the first step should be to enable the teachers to learn more about it, before using GIS as a standard teaching tool. A great interest expressed in the study by the teachers, particularly those of younger age, in attending GIS training workshops is extremely promising. However, the concept of such activities should be designed carefully, in order not to deter the study participants from using this technology in education.

In a broader context, this research should be understood as the first step towards reviewing the overall situation concerning the teachers' perspective on integration of geospatial technologies in geography teach- ing in Bosnia and Herzegovina, but also throughout the Southeast Europe. Namely, all countries in this region share a similar history of education development and face similar challenges in the current situation. Therefore, it would be both interesting and beneficial to make a number of comparative studies of this type in other countries as well, which would establish certain regular patterns in the general degree of efficiency of the modernization of geographical education in the transition countries. Of course, the requirement would also be to extend the regional scope of research across Bosnia and Herzegovina, since this study has covered only two emblematic regions rather than the entire country. On the other hand, some follow-up studies should be focused more specifically on those geography teachers who have already made certain progress in terms of application of new teaching strategies based on geospatial technology.

As far as the limitations of the current study are concerned, it is worth noting that the survey has covered a convenience sample made of those geography teachers who have decided to participate in professional development workshops, and they have not been selected randomly. This fact could have a certain impact on the results. Equally, there is a great likelihood that some respondents have provided certain answers that were not thought out well, due to an excessive number of questions in the original survey. What is more, it appears that for many respondents GIS technology is still a completely unknown area, which is why some of the questions turned out to be confusing and baffling for them. Therefore, some further studies should take this concern into account, with the belief that such types of surveys will have a greater significance once a greater number of teachers gain an insight into some practical aspects of GIS (through educational training or otherwise). Also, there is need to extend future research to other regions in Bosnia and Herzegovina (and possibly neighboring countries), so that sample size would become more comprehensive and representative.

\section{References}

Afshari, M., Abu Bakar, K., Su Luan, W., Abu Samah, B., \& Say Fooi, F. (2009). Factors affecting teachers' use of information and communication technology. International Journal of Instruction, 2(1), 77-104. Akinyemi, F. O. (2016). Technology use in Rwandan secondary schools: an assessment of teachers' attitudes towards geographic information systems (GIS). International Research in Geographical and Environmental Education, 25(1), 20-35. doi:10.1080/ 10382046.2015 .1106848
Anđelković, S., \& Pavlović, D. (2015). New media in teaching of geography: Literature review. Bulletin of the Serbian geographical society, 95(4), 173-194. doi:10.2298/GSGD1504173A

Arnold, M. L., Newman, J. H., Gaddy, B. B., \& Dean, C. B. (2005). A Look at the Condition of Rural Education Research: Setting a Direction for Future Research. Journal of Research in Rural Education, 20(6), 1-25. 
Baker, T. R., Kerski, J. J., Huynh, N. T., Viehrig, K., \& Bednarz, S. W. (2012). Call for an Agenda and Center for GIS Education Research. Review of International Geographical Education Online, 2(3), 254-288.

Baker, T. R., Battersby, S., Bednarz, S. W., Bodzin, A. M., Kolvoord, B., Moore, S., Sinton, D., \& Uttal, D. (2015). A Research Agenda for Geospatial Technologies and Learning. Journal of Geography, 114(3), 118-130. doi:10.1080/00221341.2014.950684

Bartha, G. (2010). Objectives of GIS teaching in higher education - Developing experts or training teachers? In K. Donert (Ed.), Using Geoinformation in European Geography education, Vol. IX (pp. 74-81). Rome: International Geographic Union, Home of Geography.

Bednarz, S. W., \& Van Der Schee, J. (2006). Europe and the United States: the implementation of geographic information systems in secondary education in two contexts. Technology, Pedagogy and Education, 15(2), 191-205. doi:10.1080/14759390600769573

Busch, T. (1995). Gender differences in self-efficacy and attitudes toward computers. Journal of Educational Computing Research, 12(2), 147-158. doi:10.2190/ h7e1-xmm7-gugb-3hwr.

Çepni, O. (2013). The Use of Geographic Information Systems (GIS) in Geography Teaching. World Applied Sciences Journal, 25(12), 1684-1689. doi:10.5829/ idosi.wasj.2013.25.12.1452

Clark, A. M., Monk, J., \& Yool, S. R. (2007). GIS Pedagogy, Web-based Learning and Student Achievement. Journal of Geography in Higher Education, 31(2), 225-239. doi:10.1080/03098260601063677

Colley, A., \& Comber, C. (2003). Age and gender differences in computer use and attitudes among secondary school students: what has changed? Educational Research, 45(2), 155-165. doi:10.1080/0013188032000103235

Collins, L., \& Mitchell, J. T. (2019). Teacher training in GIS: what is needed for long-term success? International Research in Geographical and Environmental Education, 28(2), 118-135. doi:10.1080/103820 46.2018.1497119

Crocco, M. S., Cramer, J., \& Meier, E. B. (2008). (Never) Mind the gap!: Gender equity in social studies research on technology in the twenty-first century. Multicultural Education and Technology Journal, 2(1), 19-36. doi:10.1108/17504970810867133

Czigány, S., Császár, Z., Kiss, K., Halmai, Á., Lóczy, D., Nagyváradi, L., \& Pirkhoffer, E. (2018). Playing on reality: do geomodels improve the perception of geographical terms? International Research in Geographical and Environmental Education, 27(2), 149164. doi:10.1080/10382046.2017.1320896

Demirci, A. (2009). How do teachers approach new technologies: Geography teachers' attitudes to- wards Geographic Information System (GIS). European Journal of Educational Studies, 1(1), 43-53.

De Winter, J. C. F., \& Dodou, D. (2010). Five-Point Likert Items: $t$ test versus Mann-Whitney-Wilcoxon. Practical Assessment, Research \& Evaluation 15(11), 1-16.

Donert, K. (2014). Building Capacity for Digital Earth Education in Europe. In R. M. Gonzalez, \& K. Donert (Eds.), Innovative Learning Geography in Europe: New Challenges for the 21st Century. (pp. 9-19). Newcastle upon Tyne: Cambridge Scholars Publishing.

Drešković, N., \& Avdić, B. (2017). Didactic aspects of GIS application in geographic school education. Geographical Review, 38, 133-144.

Höhnle, S., Schubert, J. C., \& Uphues, R. (2011). Barriers to GI(S) Use in Schools - A Comparison of International Empirical Results. In T. Jekel, A. Koller, K. Donert, \& R. Vogler (Eds.), Learning with GI 2011 (pp. 148-158). Berlin/Offenbach: Herbert Wichmann Verlag.

Höhnle, S., Fögele, J., Mehren, R., \& Schubert, J. C. (2016). GIS Teacher Training: Empirically-Based Indicators of Effectiveness. Journal of Geography, 115(1), 12-23. doi:10.108o/oo221341.2015.1016546

Howley, A., Wood, L., \& Hough, B. (2011). Rural Elementary School Teachers' Technology Integration. Journal of Research in Rural Education, 26(9), 1-13.

Jo, I., Hong, J. E., \& Verma, K. (2016). Facilitating spatial thinking in world geography using Web-based GIS. Journal of Geography in Higher Education, 40(3), 442-459. doi:10.1080/03098265.2016.1150439

Johansson, T. (2003). GIS in Teacher Education - Facilitating GIS Applications in Secondary School Geography. In K. Virrantaus \& H. Tveite (Eds.), Proceedings of the ScanGIS'2003 - The 9th Scandinavian Research Conference on Geographical Information Science (pp. 285-293). Helsinki, Finland: Department of Surveying, Helsinki University of Technology.

Karolčík, Š., Čipková, E., \& Mázorová, H. (2016). Application of digital technologies in the geography teaching process from the teachers' perspective. International Research in Geographical and Environmental Education, 25(4), 328-343. doi:10.1080/10382 046.2016 .1207992

Kay, R. (2006). Addressing Gender Differences in Computer Ability, Attitudes and Use: The Laptop Effect. Journal of Educational Computing Research, 34(2), 187-211. doi:10.2190/gblq-883y-xqma-fcah

Kerr, S. (2016). Integrating geospatial technologies into existing teacher education coursework: Theoretical and practical notes from the field. Contemporary Issues in Technology and Teacher Education, 16(3), 328-347. 
Kerski, J. J. (2003). The Implementation and Effectiveness of Geographic Information Systems Technology and Methods in Secondary Education. Journal of Geography, 102(3), 128-137. doi:10.1080/00221340308978534

Kerski, J. J., Demirci, A., \& Milson, A. J. (2013). The Global Landscape of GIS in Secondary Education. Journal of Geography, 112(6), 232-247. doi:10.1080/o 0221341.2013.801506

Kerski, J. J. (2015). Geo-awareness, Geo-enablement, Geotechnologies, Citizen Science, and Storytelling: Geography on the World Stage. Geography Compass, 9(1), 14-26. doi:10.1111/gec3.12193

Kim, M., Bednarz, R., \& Lee, S. I. (2011). GIS Education for Teachers in South Korea: Who Participates and Why? Journal of the Korean Geographical Society, 46(3), 382-395.

Komlenović, Đ., Manić, E., \& Malinić, D. (2013). The Geographic Information System (GIS) in secondary education in Serbia. Perspectives in Education, 31(1), 96-101.

Král, L., \& Řezníćková, D. (2013). The proliferation and implementation of GIS as an educational tool at gymnasiums/grammar schools in Czechia. Geografie, 118(3), 265-283.

Kwan, M. P. (2002). Is GIS for Women? Reflections on the critical discourse in the 1990s. Gender, Place, and Culture, 9(3), 271-279. doi:10.1080/0966369022 000003888

Lay, J. G., Chen, Y. W., \& Chi, Y. L. (2013). GIS Adoption Among Senior High School Geography Teachers in Taiwan. Journal of Geography, 112(3), 120-130. doi:10.1080/00221341.2012.682226

Macía Arce, X. C., Rodríguez Lestegás, F., \& Armas Quintá, F. X. (2017). Notes for a didactic model of critical geography. Analysis and evaluation of a classroom experience with university students from Galicia (Spain). Geographica Pannonica, 21(3), 191-197. doi:10.5937/GeoPan1703124M

McClurg, P. A., \& Buss, A. (2007). Professional Development: Teachers Use of GIS to Enhance Student Learning. Journal of Geography, 106(2), 79-87. doi:10.1080/00221340701477831

Mead, S. E., Batsakes, P., Fisk, A. D., \& Mykityshyn, A. (1999). Application of Cognitive Theory to Training and Design Solutions for Age-related Computer Use. International Journal of Behavioral Development, 23(3), 553-573. doi:10.1080/016502599383694

Meelissen, M. R. M., \& Drent, M. (2008). Gender differences in computer attitudes: Does the school matter? Computers in Human Behavior, 24(3), 969985. doi:10.1016/j.chb.2007.03.001

Metoyer, S., \& Bednarz, R. (2017). Spatial Thinking Assists Geographic Thinking: Evidence form a Study Exploring the Effects of Geospatial Technol- ogy. Journal of Geography, 116(1), 20-33. doi:10.1080/ o0221341.2016.1175495

Montello, D. R., Lovelace, K. L., Golledge, R. G., \& Self, C. M. (1999). Sex-Related Differences and Similarities in Geographic and Environmental Spatial Abilities. Annals of the Association of American Geographers, 89(3), 515-534. doi:10.1111/0004-5608.00160

Riihelä, J., \& Mäki, S. (2015). Designing and Implementing an Online GIS Tool for Schools - The Finnish Case of the PaikkaOppi Project. Journal of Geography, 114(1), 15-25. doi: 10.1080/o0221341.2014.897362

Russell, M., Bebell, D., O’Dwyer, L., \& O'Connor, K. (2003). Examining Teacher Technology Use: Implications for Preservice and Inservice Teacher Preparation. Journal of Teacher Education, 54(4), 297-310. doi: $10.1177 / 0022487103255985$

Sang, G., Valcke, M., Van Braak, J., \& Tondeur, J. (2010). Student teachers' thinking processes and ICT integration: Predictors of prospective teaching behaviors with educational technology. Computers \& Education, 54(1), 103-112. doi:10.1016/j.compedu.2009.07.010

Schubert, J. C., Höhnle, S., \& Uphues, R. (2012). Which Chances Do Teachers See in GI(S) Usage in the Classroom? In T. Jekel, A. Car, J. Strobl, \& G. Griesebner (Eds.), GI_Forum 2012: Geovizualisation, Society, and Learning (pp. 283-291). Berlin/Offenbach: Herbert Wichmann Verlag.

Sharp, J. (2005). Geography and gender: feminist methodologies in collaboration and in the field. Progress in Human Geography, 29(3), 304-309. doi:10.1191/0309132505ph55opr

Shin, E. E., Milson, A. J., \& Smith, T. J. (2016). Future Teachers' Spatial Thinking Skills and Attitudes. Journal of Geography, 115(4), 139-146. doi:10.1080/o 0221341.2015.1100654

Slocum, T. A., Blok, C., Jiang, B., Koussoulakou, A., Montello, D. R., Fuhrmann, S., \& Hedley, N. R. (2001). Cognitive and Usability Issues in Geovisualization. Cartography and geographic information science, 28(1), 61-75. doi:10.1559/152304001782173998

Stephens, M. (2013). Gender and the GeoWeb: divisions in the production of user-generated cartographic information. GeoJournal, 78(6), 981-996. doi:10.1007/s10708-013-9492-Z

Stojšić, I., Ivkov-Đigurski, A. \& Marčić, O. (2019). The Readiness of Geography Teachers to use Mobile Devices in the Context of Immersive Technologies Integration into the Teaching Process. Geographica Pannonica, 23(2), 121-133. doi:10.5937/gp23-20762

Svatonová, H., \& Mrázková, K. (2010). Geoinformation Technologies: New Opportunities in Geography Education? In M. Valenčič Zuljan and J. Vogrinc (Eds.), Facilitating Effective Student Learning through Teacher Research and Innovation (pp. 
331-347). Ljubljana: Faculty of Education, University of Ljubljana.

Teo, T. (2008). Pre-service teachers' attitudes towards computer use: A Singapore survey. Australasian Journal of Educational Technology, 24(4), 413-424. doi:10.14742/ajet.1201

Wang, Y. H., \& Chen, C. M. (2013). GIS Education in Taiwanese Senior High Schools: A National Survey among Geography Teachers. Journal of Geography, 112(3), 75-84. doi:10.1080/0o221341.2011.637227

Yuda, M., Itoh, S., \& Johansson, T. (2009). Geographic Information Systems in Upper Secondary School Education in Japan and Finland: A Comparative Study. The Shin-Chiri (The New Geography), 57, 156165. 